\title{
Phenolic compounds and total antioxidant activity determination in rosemary and oregano extracts and its use in cheese spread
}

\author{
Determinação de compostos fenólicos e atividade antioxidante \\ total de extratos de alecrim e orégano e sua aplicação \\ em queijo à base de ricota
}

\author{
Renata Dinnies Santos ${ }^{1}$; Kalidas Shetty ${ }^{2}$; \\ Alessandra Lourenço Cecchini ${ }^{3}$, Lucia Helena da Silva Miglioranza ${ }^{4 *}$
}

\begin{abstract}
Natural antioxidants added to foods may have a physiological impact on human health, particularly because they may reduce the risk of illnesses or they promote the delay of damaging free radicals effect, like cardiovascular diseases, intestinal cancer or infections symptoms. The best conditions for the extraction of phenolic compounds from Rosmarinus officinalis L. (rosemary) and Origanum vulgare (oregano) was established, and the antioxidant activity from raw extracts was demonstrated based on inhibition of DPPH free radical formation and microsome lipid peroxidation. The extracts obtained were added, separately, to a fresh cheese spread (FCS) and the product was evaluated for sensory qualities. The best condition for extraction of phenolic compounds was $75 \%$ ethanol in 8 hours running time for rosemary $(0.46 \mathrm{mg} \mathrm{GAE} / \mathrm{mL} \pm 0.01 \mathrm{w} / \mathrm{v})$, and $40 \%$ ethanol in 7.5 hours running time for oregano $(2.57 \mathrm{mg} \mathrm{GAE} / \mathrm{mL} \pm 0.02 \mathrm{w} / \mathrm{v})$. The rosemary extract showed high antioxidant activity in both tests. The product with concentrated rosemary extracts had $96 \mathrm{mg}$ GAE/100g in the final blend and 76\% acceptance index. The fresh cheese spread (FCS) with Origanum vulgare extract had $396 \mathrm{mg}$ GAE/100g in the final blend, with $91 \%$ acceptance index.
\end{abstract}

Key words: Free radicals, antioxidants, bioactive phytochemicals, total phenolic compounds

\section{Resumo}

Compostos antioxidantes naturais adicionados em alimentos podem ter um impacto fisiológico sobre a saúde humana, principalmente porque podem reduzir o risco de doenças ou promover retardamento dos danos provocados pelo efeito de radicais livres, como as doenças cardiovasculares, câncer intestinal, infecções intestinais, entre outras. Neste trabalho, foram otimizadas as condições de extração de compostos fenólicos das especiarias Rosmarinus officinalis L. (alecrim) e Origanum vulgare (orégano), e a atividade antioxidante nos extratos brutos foi avaliada pela inibição do radical DPPH e pela peroxidação lipídica de microssoma. Os extratos obtidos foram adicionados, separadamente, ao queijo à base de ricota (FCS), e o produto foi avaliado sensorialmente. As condições ótimas de extração dos compostos fenólicos foram $75 \%$ de etanol em 8 horas de operação para Rosmarinus officinalis L. $(0,46$ $\mathrm{mg} \mathrm{GAE} / \mathrm{ml} \pm 0,01 \mathrm{p} / \mathrm{v})$ e $40 \%$ de etanol em 7,5 horas de operação para Origanum vulgare $(2,57 \mathrm{mg}$ $\mathrm{GAE} / \mathrm{mL} \pm 0,02 \mathrm{p} / \mathrm{v}$ ). O extrato de alecrim apresentou maior atividade antioxidante em ambos os testes.

${ }^{1}$ DSc. Food Science Pos Graduate Program. University of Londrina, UEL, Brazil. E-mail: renatadinnies@gmail.com

${ }^{2} \mathrm{PhD}$. Department of Food Science. University of Massachusetts, USA. E-mail: kalidas@foodsci.umass.edu

${ }^{3}$ DSc. Department of Experimental Pathology, UEL, Brazil. E-mail: alcecchini@uel.br

${ }^{4}$ DSc. Department of Food Science and Technology. Campus Universitário. Rod. Celso Garcia Cid. POBox 6001 University of Londrina. Londrina, PR, Brazil. E-mail: luciah@uel.br

${ }^{*}$ Author for corespondence 
O produto contendo extrato concentrado de alecrim $(9,60 \mathrm{mg} \mathrm{GAE} / \mathrm{mL}$ p/v) atingiu $76,0 \%$ de aceitação, com compostos fenólicos na concentração de $96 \mathrm{mg} \mathrm{GAE} / 100 \mathrm{~g}$ de produto. O produto lácteo formulado com extrato de orégano apresentou concentração de compostos fenólicos de $396 \mathrm{mg}$ GAE/100g de produto, com índice de aceitação de $91,1 \%$.

Palavras-chave: Radicais livres, antioxidantes, fitoquímicos bioativos, compostos fenólicos totais

\section{Introduction}

Several studies have indicated that the consumption of antioxidant compounds protect cells against the damage of reactive oxygen species such as singlet oxygen, superoxide, peroxyl radicals, hydroxyl radicals and peroxynitrite (YANG et al., 2008). Phenolic compounds belong to a class of antioxidants that interact with free radical species and are consumed during the reaction (RAMALAKSHMI et al., 2009).

The evidence for antioxidant effect of spices and herbs in food systems was initially determined by Chipault et al. (1952) studying 32 spices, and among these rosemary and sage were considered the most effective. Subsequently, the antioxidant function was also confirmed in oregano, thyme, ginger, pepper, mustard and cinnamon, amongst others.

Currently, the antioxidant properties of rosemary are well recognized. It is a free radical scavenger possibly due to metal chelator and superoxide radical inhibition (MORENO et al., 2006). The lipid labile antioxidant activity of rosemary leaf extracts is mainly due to the presence of phenolic diterpens carnosol and carnosic acid. Other phenolic diterpenes such as rosmanol, epirosmanol and methyl-epirosmanol are present in smaller quantities and also contribute to the antioxidant activity of rosemary extracts (AYRANCI; ERKAN; AYRANCI, 2008).

Rosmarinic acid, a caffeic acid ester, also appears as an important component in extracts of rosemary for having superior antioxidant activity than $\alpha$-tocopherol and butylated hydroxyl toluene (BHT) (TEPE, 2008). Many beneficial functionalities of rosmarinic acid, which include anti-inflammation (HUANG et al., 2009), anti-mutagenicity
(FURTADO et al., 2008), prevention of Alzheimer's disease (HAMAGUCHI et al., 2009), apoptosis induction of colorectal cancer cells (XAVIER et al., 2009), etc., have been recently reported in addition to its potent antioxidant activity.

Oregano is widely used as a condiment and its flavor and smell are greatly appreciated throughout the world for culinary applications. Furthermore, this herb has antimicrobial and antioxidant properties (LOIZZO et al., 2009; SIMITZIS et al., 2008). According to Sahin, Bayramoglu and Sumni (2008) the main components of Origanum vulgare L. essential oil are thymol $(650-750 \mathrm{mg} / \mathrm{mL})$ followed by p-cymene (60-85 mg/mL), carvacrol (40-60 mg/ $\mathrm{mL}), \gamma$-terpinene $(35-50 \mathrm{mg} / \mathrm{mL}), \beta$-myrcene $(15$ $\mathrm{mg} / \mathrm{mL})$ and $\alpha$-terpinene $(10-15 \mathrm{mg} / \mathrm{mL})$. Oregano extracts have been effective, and in some cases, having higher levels of antioxidant activity than BHT and BHA (TARHAN et al., 2007).

The use of whey proteins as specific ingredients in functional dairy foods has increased due to improvements in technological processes to produce commercially attractive concentrated protein, isolated protein, or more recently, enriched protein fractions (BALDASSO; BARROS; TESSARO, 2011; BHATTACHARJEE; BHATTACHARJEE; DATTA, 2006). The two proteins present in greater quantity in milk serum are $\alpha$ - lactalbumin and $\beta$-lactoglobulin, which are globular proteins with approximately $70-80 \%$ of the total protein content (BRODKORB et al., 2006) and have defined physiological properties. The usefulness of rosemary and oregano on the preservation of food containing these proteins is still unclear.

Based on integrating the above background and rationale the purpose of this study was to evaluate the concentration of phenolic compounds in alcoholic 
extracts of Origanum vulgare and Rosmarinus officinalis L. and its antioxidant activity, and to develop and evaluate sensory a fresh cheese spread (FCS), containing the phytochemicals extracts.

\section{Material and Methods}

The herbs were acquired in a local market in Londrina, Parana State, Brazil. After 15 days following collection they were partially dehydrated (moisture 12.1\% and 10.3\% for Origanum vulgare and Rosmarinus officinalis L., respectively) and minced.

Optimization of extraction of phenolics from the herbs was carried out using response surface methodology, based on a factorial design $3^{2}$. The design variables were ethanol concentration $(50,60$ and $70 \%)$ and time extraction (2, 4 and $6 \mathrm{~h})$.

Origanum vulgare and Rosmarinus officinalis L. extracts were obtained by extraction with the combination of solvents ethanol and water. Ten grams $(10 \mathrm{~g})$ of dried material samples (Origanum vulgare and Rosmarinus officinalis L.) were extracted with 200 and $150 \mathrm{~mL}$ of solvent, respectively, at different times, at room temperature, under constant agitation. After the extraction, the samples were filtered through vacuum filtration and stored under refrigeration and kept away from light.

After obtaining the response for each point of the initial planning, was performed the steepest ascent, followed by a second order factorial design $\left(2^{2}\right)$ with two located central points and star points (Table 1).

Table 1. Factorial design of second order for the phenolic compounds extraction process from Origanum vulgare and Rosmarinus officinalis L.

\begin{tabular}{cccccccc}
\hline & \multicolumn{3}{c}{ Origanum vulgare } & \multicolumn{3}{c}{ Rosmarinus officinalis L. } \\
\hline \multicolumn{2}{c}{ Coded variables* } & \multicolumn{2}{c}{ Not coded vabiables* } & \multicolumn{2}{c}{ Coded variables* } & \multicolumn{2}{c}{ Not coded vabiables* } \\
\hline X1 & X2 & X1 (\%) & X2 (h) & X1 & X2 & X1 (\%) & X2 (h) \\
\hline-1 & -1 & 35,0 & 6,5 & -1 & -1 & 72,5 & 7,0 \\
-1 & +1 & 35,0 & 8,5 & -1 & +1 & 72,5 & 9,0 \\
+1 & -1 & 45,0 & 6,5 & +1 & -1 & 77,5 & 7,0 \\
+1 & +1 & 45,0 & 8,5 & +1 & +1 & 77,5 & 9,0 \\
$-1,414$ & 0 & 32,9 & 7,5 & $-1,414$ & 0 & 71,5 & 8,0 \\
$+1,414$ & 0 & 47,1 & 7,5, & $+1,414$ & 0 & 78,5 & 8,0 \\
0 & $-1,414$ & 40,0 & 6,1 & 0 & $-1,414$ & 75,0 & 6,6 \\
0 & $+1,414$ & 40,0 & 8,9 & 0 & $+1,414$ & 75,0 & 9,4 \\
0 & 0 & 40,0 & 7,5 & 0 & 0 & 75,0 & 8,0 \\
0 & 0 & 40,0 & 7,5 & 0 & 0 & 75,0 & 8,0 \\
\hline
\end{tabular}

* X1: \% ethanol; X2: time extraction.

Source: Elaboration of the authors.

The statistical analysis of data was performed using software Statistic 5.0. Experimental data were fitted to a second-order polynomial model and regression coefficients obtained. The generalized second-order polynomial model used in the response surface analysis was as follows (equation 01).

$$
\mathrm{Y}=\beta_{0}+\sum_{i=1}^{2} \beta_{i} X_{i}+\sum_{i=1}^{2} \beta_{i} X_{i}+\beta_{\mathfrak{2}} X_{1} X_{2}
$$

where $\beta_{0}, \beta_{\mathrm{i}}, \beta_{\mathrm{ii}}$ and $\beta_{12}$ are the regression coefficients for intercept, linear, quadratic and interaction term, respectively, and $\mathrm{X}_{1}$ and $\mathrm{X}_{2}$ are the 
independent variables.

After optimization of the extraction conditions, the extracts were concentrated in a TECNAL TE $394 / 3$ incubator with air circulation, at $35^{\circ} \mathrm{C}$ for $2.5 \mathrm{~h}$.

\section{Total Phenolics}

Total phenolics were determined according to the methodology described by Singleton, Orthofer and Lamuela-Raventos (1999). One milliliter of alcoholic extract of Origanum vulgare and Rosmarinus officinalis L. was added to $1 \mathrm{~mL} 95 \%$ ethanol, $5 \mathrm{~mL}$ distilled water and $0.5 \mathrm{~mL} 1 \mathrm{~N}$ FolinCiocalteu reagent. After $5 \mathrm{~min}, 1 \mathrm{~mL} 5 \% \mathrm{Na}_{2} \mathrm{CO}_{3}$ was added, and the reagent mixture was kept $60 \mathrm{~min}$ at room temperature. The quantification of phenolic compounds was performed spectrophotometrically by measuring the absorbance in UV-VIS spectrophotometer Shimadzu 1240, at $725 \mathrm{~nm}$, and a gallic acid $(10-100 \mu \mathrm{g} / \mathrm{mL})$ in $95 \%$ ethanol was used for obtaining a standard curve.

Antioxidant Activity Inhibition System of Radical 1,1-diphenyl-2-picrhydrazyl (DPPH)

To assess the capacity of herbal extracts to inhibit the sequestration activity of the DPPH radical, the standard methodology as modified by Chun et al. (2005) was used. Three milliliters of DPPH $60 \mu \mathrm{M}$ in ethanol were added to $1 \mathrm{~mL}$ of alcoholic extract of Origanum vulgare and Rosmarinus officinalis L., and incubated at room temperature for $15 \mathrm{~min}$. The measuring was performed at $517 \mathrm{~nm}$ absorbance and the antioxidant activity was calculated as inhibition $\%$ of DPPH radical formation, demonstrated in the equation 02 . As a control, $1 \mathrm{~mL}$ of $95 \%$ ethanol was used to replace the extracts.

$$
\% \text { inhibition }=\left(\frac{\mathrm{A}_{517}^{\text {control }}-\mathrm{A}_{517}^{\text {extract }}}{\mathrm{A}_{517}^{\text {control }}}\right) \cdot 100
$$

\section{MDA (malondialdehyde) Assay}

Aldehydes are often produced when lipoperoxides are metabolized by aerobic organisms. MDA is one of the most abundant aldehydes derived from tissue lipid peroxidation. The quantification of MDA was held in the presence of rats liver microsomes and alcoholic extracts of oregano and rosemary. The methodology was based on the use of thiobarbituric acid, modified by Cechini, Aruoma and Halliwell (1990). One milliliter of the homogenate, prepared from rats liver microsomes was added to $100 \mu \mathrm{L} 1$ $\mathrm{mM} \mathrm{FeCl}, 100 \mu \mathrm{L} 1 \mathrm{mM}$ ascorbic acid, $1.0 \mathrm{~mL}$ $2.8 \%$ trichloracetic acid, $1.0 \mathrm{~mL} 1.0 \%$ thiobarbituric acid and $2.0 \mathrm{~mL}$ of alcoholic extract of oregano or rosemary. As a control $2.0 \mathrm{~mL}$ distilled water was used.

The treatments, the control and the comparison

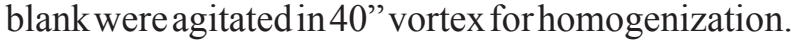
Then, the tubes were placed in water-bath at $95^{\circ} \mathrm{C}$ for $20 \mathrm{~min}$, with subsequent ice bath for cooling. The organic phase was extracted with $2.0 \mathrm{~mL}$ of butanol and the rest was stirred again using a vortex mixer. After stirring, the mixture was centrifugated at $2.167 \mathrm{x} \mathrm{g}$ for $15 \mathrm{~min}$. The absorbance measuring was at $535 \mathrm{~nm}$ and $572 \mathrm{~nm}$, and the calibration was performed with butanol. The results of lipid peroxidation were expressed in nanomoles of malondialdehyde/mL of extract, using 156 as the molar extinction coefficient of malondialdehyde.

\section{Fresh Cheese Spread (FCS) Formulation}

Commercial ricotta cheese and $15 \%$ of milk cream $(25.0 \%$ fat $)$ were the basis of the formulation, in wich were added the concentrated extracts of herbs and other ingredients (Table 2). The volume of extract added to formulation was established after quantification of phenolic compounds in the concentrated extracts, taking into account the Recommended Daily Intake for phenolic compounds (1 g/day) (SCALBERT; WILLIAMSON, 2000) and the sensory characteristics of the product. 
Table 2. Fresh cheese spread formulations.

\begin{tabular}{lcc}
\cline { 2 - 3 } & \multicolumn{2}{c}{ Formulations } \\
\cline { 2 - 3 } & Origanum vulgare & Rosemarinus officinalis $\mathrm{L}$. \\
\hline Basis $(\mathrm{g})$ & 100 & 100 \\
Sodium chloride $(\mathrm{g})$ & 1,4 & 1,4 \\
Monosodium glutamate $(\mathrm{g})$ & 1,4 & 1,4 \\
Dehydrated oregano $(\mathrm{g})$ & 0,4 & 0,0 \\
Fine herbs $(\mathrm{g})$ & 0,0 & 0,4 \\
Concentrated extract $(\mathrm{mL})$ & 22,0 & 10,0 \\
\hline
\end{tabular}

Source: Elaboration of the authors.

\section{Sensory Evaluation}

The formulations containing oregano and rosemary extracts were evaluated for sensory properties through an acceptance test and ideal scale, using 50 tasters (LAWLESS; HEYMANN, 1998). To assess the acceptability of the two formulations, a 9-point hedonic scale was used. The ideal scale was used to evaluate the parameters: color, bitter taste, acidity, salty taste and firmness (texture). The samples randomly coded with three-digit numbers were served in a monadic form in individual booths, at $25^{\circ} \mathrm{C}$.

\section{Physical and Chemical Characterization}

The physical and chemical (gross composition, titratable acidity expressed in lactic acid \%, pH and water activity) analyses for the commercial ricotta and FCS were performed according to the AOAC (1995) methods.

\section{Results and Discussion}

Extraction of Phenolic Compounds from Origanum vulgare and Rosmarinus officinalis $L$.

The efficiency of the extraction of phenolic compounds is influenced by multiple parameters, such as temperature, time of extraction, solvent polarity, among others, and their effects may be either independent or interactive. Selection of the most appropriate conditions and solvents for extraction is required to maximize the degree of recovery for the most important phenolic compounds contained in the matrix (SUHAJ, 2006). In this experiment, the response surface methodology was used as tool in the optimization of the experimental conditions.

The experimental design was planed to assess the impact of two factors (independent variables), time of extraction and ratio between solvents ethanol and water for the extraction of phenolic compounds (dependent variable) from oregano and rosemary.

The optimum conditions for extraction of phenolic compounds from rosemary were obtained using $75 \%$ ethanol in $8 \mathrm{~h}$ of operation (Figure 1). For oregano, the optimal conditions for extraction of phenolic compounds were obtained when it was used $40 \%$ ethanol in $7.5 \mathrm{~h}$ of operation (Figure 2). The optimal conditions of extraction were different for both raw materials due to the likely differences in chemical nature and polarity of the phenolic compounds.

According to Chun et al. (2005), improved results in the extraction of phenolic compounds from commercial or clonal oregano were obtained through the use of $60 \%$ ethanol in $24 \mathrm{~h}$ of extraction. In those conditions, the authors found $35.43 \mathrm{mg}$ GAE $/ \mathrm{mL}(\mathrm{w} / \mathrm{v})$ phenolic compounds in commercial oregano and $55.35 \mathrm{mg}$ GAE/mL (w/v) in the clonal oregano. It is important to mention that the extracts were concentrated. According to the authors, commercial herb extracts lack uniformity in the phenolic concentration and this is an essential requirement for use as an ingredient in functional foods. 
Figure 1. Response surface plot for the effect of ethanol concentration (\%) and time of extraction (h) on total phenolic content from Rosmarinus officinalis L. alcoholic extract.

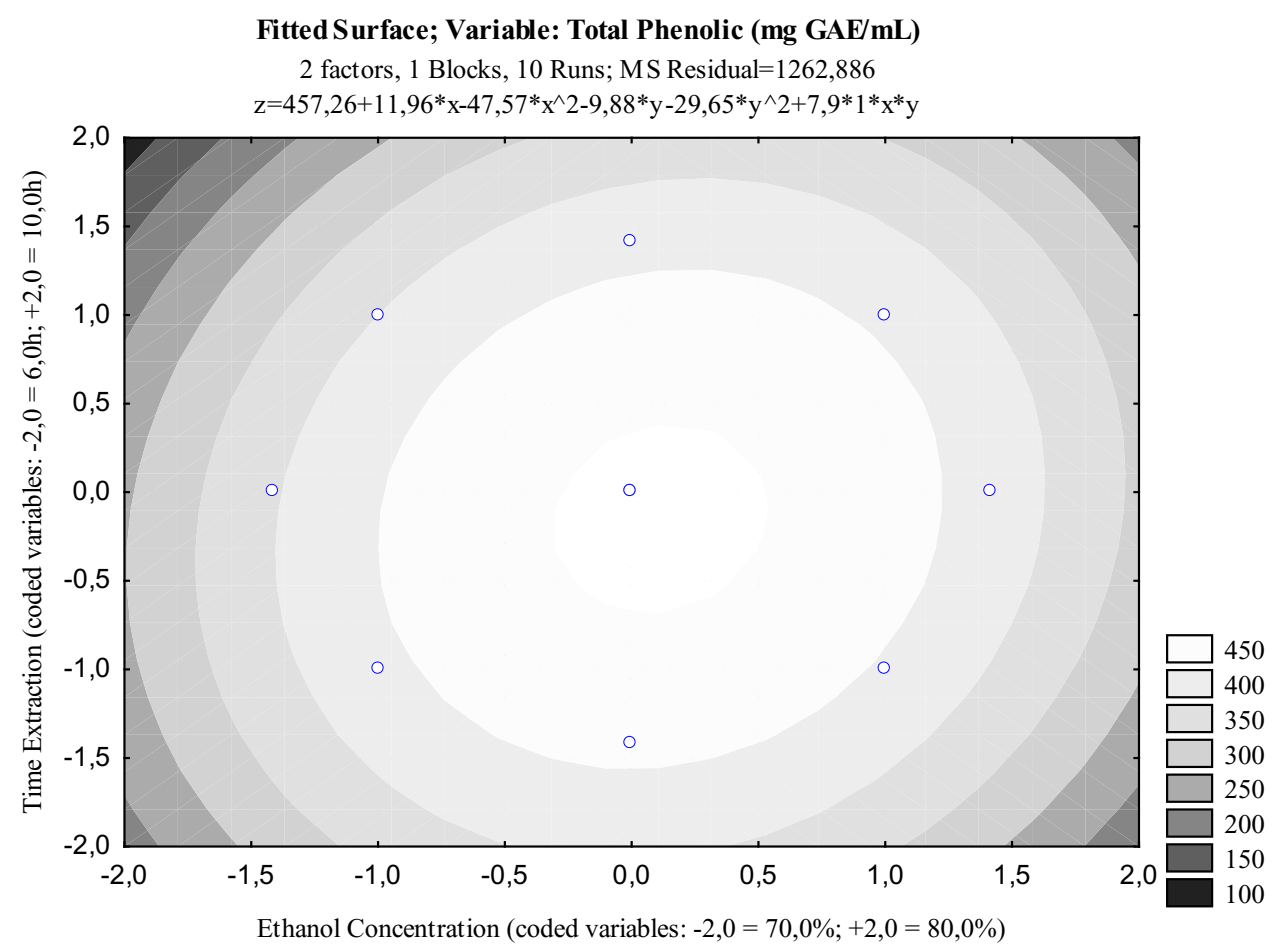

Source: Elaboration of the authors.

Figure 2. Response surface plot for the effect of ethanol concentration (\%) and time of extraction (h) on total phenolic content from Origanum vulgare alcoholic extract.

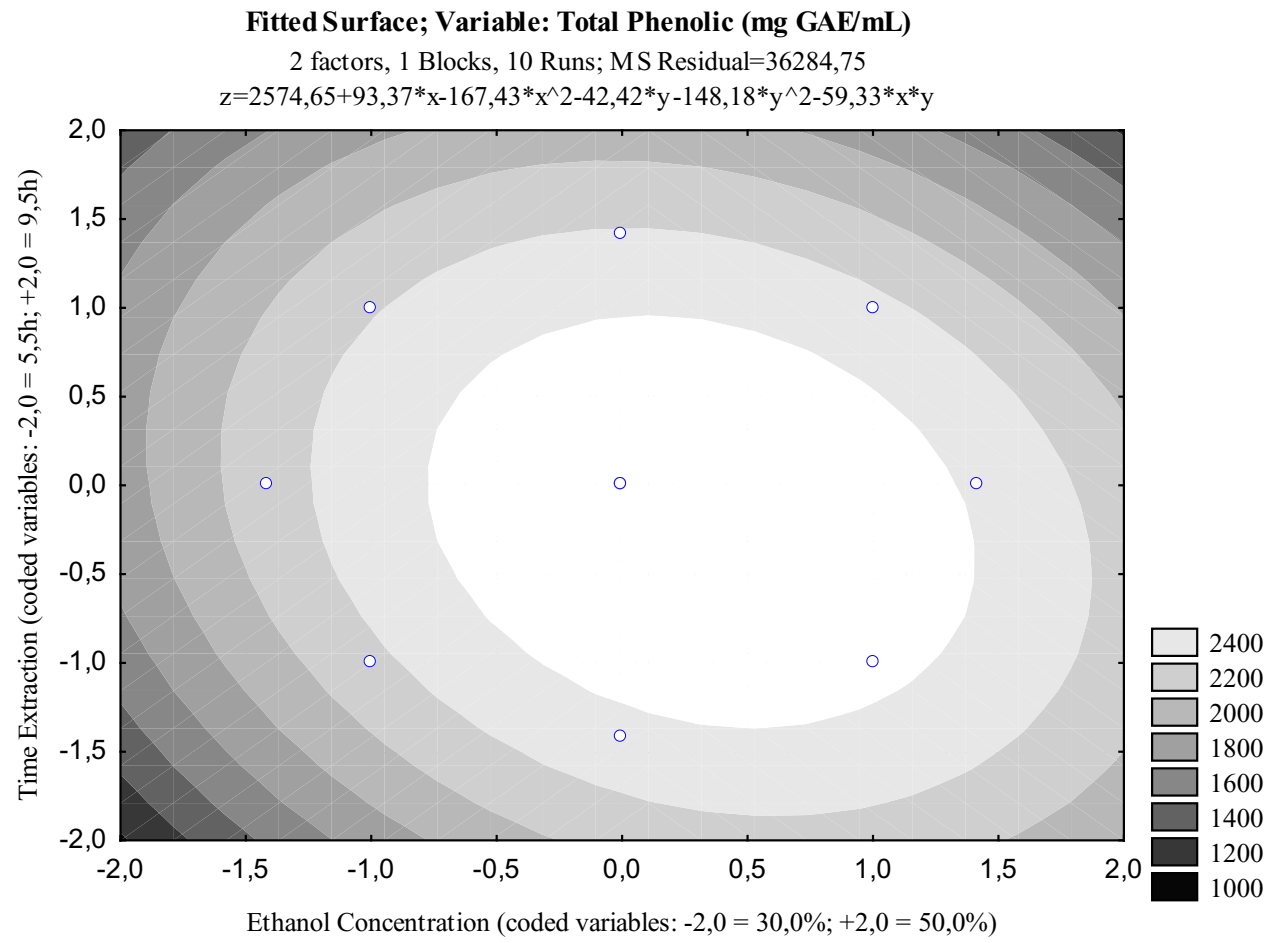

Source: Elaboration of the authors. 
In the present experiments concentrations of $2.57 \mathrm{mg} \mathrm{GAE} / \mathrm{mL} \pm 0.02 \mathrm{w} / \mathrm{v}$ of total phenolics from oregano crude extracts was obtained. The total phenolic content found in the extract, after solvent evaporation (ethanol), was over 18.0 $\mathrm{mg}$ GAE $/ \mathrm{mL}(\mathrm{w} / \mathrm{v})$, indicating good dosage for application of the extract as ingredient in dairy foods. This concentration was considered adequate when compared with Brazilian red wines phenolics of 1.041 - $1.958 \mathrm{mg}$ GAE/mL (GRANATO; KATAYAMA; CASTRO, 2010).

The concentration of phenolic compounds of $0.46 \mathrm{mg} \mathrm{GAE} / \mathrm{mL} \pm 0.01$ obtained from rosemary extracts was significantly lower $(\mathrm{P}<0.01)$ than the concentration obtained from oregano in the diluted extract and $9.60 \mathrm{mg} \mathrm{GAE} / \mathrm{mL}$ in the concentrated extract.

\section{Antioxidant Activity}

Inhibition system of radical 1,1-diphenyl-2picrahydrzyl (DPPH)

DPPH (1,1-diphenyl-2-picrylhydrazyl) is a stable free radical, which has a spare electron that makes delocalization over the whole molecule. The delocalization causes a deep violet color with absorption maxima ( $\lambda$ max) around $520 \mathrm{~nm}$. When a solution of DPPH is mixed with a substrate acting as a hydrogen atom donor, a stable non radical form of DPPH is obtained with simultaneous change of the violet color to pale yellow (LAJOLO et al., 2006). The reduction of absorbance in the presence of oregano and rosemary alcoholic extracts was compared to the absorbance reduction of the control group and expressed as the percentage of scavenged free radicals (Figure 3).

Figure 3. DPPH radical inhibition activity of alcoholic extracts of Origanum vulgare_and Rosmarinus officinalis L.

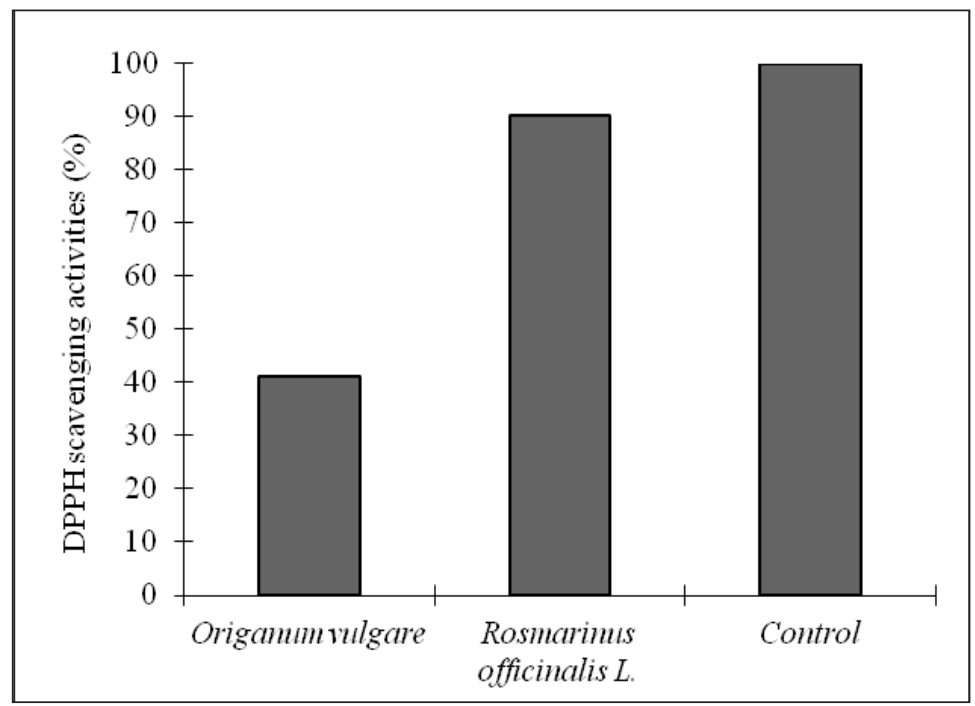

Source: Elaboration of the authors.

The rosemary alcoholic extract had higher antioxidant activity than the oregano alcoholic extract, despite the lower total phenolic content. The percent inhibition of DPPH was $90.14 \%$ for rosemary alcoholic extract and $41.16 \%$ for oregano alcoholic extract. This suggests that the physico- chemical nature of the individual phenolics in the extracts may be more important in contributing to the antioxidant activity than the total phenolic content (RODRÍGUEZ-ROJO et al., 2012). This observation indicates that a critical concentration of phenolic compounds is enough to obtain a desired 
antioxidant activity after which there is a saturation effect and the presence of additional phenolics does not increase the antioxidant activity.

The differences in antioxidant activity in this assay were largely based on the ratio of hydrophilic and hydrophobic nature of phenolics, since this method determines mainly water soluble phenolic compounds (LAJOLO et al., 2006; RODRÍGUEZROJO et al., 2012) although Kulisic et al. (2004) claim that the polarity of the substrate does not influence the methods sensitivity.

\section{TBARS Determination}

The thiobarbituric acid reactive substances test (TBARS) is based on the reaction of thiobarbituric acid (TBA) with hydro peroxide decomposition products, such as malondialdehyde (MDA), low weight aldehyde and others sub-products of lipid peroxidation. Although unspecific, it has been widely used to determine lipid peroxidation in biological systems, in cells and tissues (MONOHAN; CAPRIOLI; O'SULLIVAN, 2011). The results are expressed as nmol MDA/mL of extract used in the assay to inhibit the microsomal lipid peroxidation.

Microsomal lipid peroxidation was significantly inhibited $(\mathrm{P}<0.05)$ in the presence of oregano and rosemary alcoholic extracts (Table 3) when compared to the control. This could be evidenced by the decrease of malondialdehyde production indicating that both extracts have antioxidant activity towards biological membrane lipid peroxidation.

Table 3. Concentration of MDA (malondialdehyde).

\begin{tabular}{lcc}
\hline \multicolumn{1}{c}{ Alcoholic extract } & nmol MDA/mL & Decrease in the MDA production (\%) \\
\hline Origanum vulgare & $2.318 \pm 0.01^{\mathrm{a}}$ & 49.8 \\
Rosmarinus officinalis L. & $1.362 \pm 0.03^{\mathrm{b}}$ & 70.5 \\
Control group & $4.621 \pm 0.02$ & - \\
\hline
\end{tabular}

* Means followed by different letters in the same column differ from each other at a $5 \%$ level (Tukey).

Source: Elaboration of the authors.

Besides both extracts presented antioxidant activity, rosemary alcoholic extract reduced by $70.5 \%$ the production of malondialdehyde, indicating greater antioxidant activity than the oregano alcoholic extract (49.8\%).

This result further confirms observations that the chemical nature of phenolic compounds present in extracts may be more important in antioxidant activity than their total concentration, and, according to Rodríguez-Rojo et al. (2012), a saturation effect may occur in the presence of additional phenolic compounds.

\section{Development of Fresh Cheese Spread (FCS)}

\section{Physical and Chemical Characterization}

The formulation containing oregano extract had $396 \mathrm{mg}$ of phenolics/100g of product, which corresponds to $39.6 \%$ of the Recommended Daily Intake (SCALBERT; WILLIAMSON, 2000). The product containing rosemary extract had $96 \mathrm{mg}$ of phenolics $/ 100 \mathrm{~g}$ of product, corresponding to $9.6 \%$ of the Recommended Daily Intake.

The values of total dry extract, crude protein (total nitrogen), fat, mineral residue (ash), total carbohydrates, $\mathrm{pH}$, water activity, titratable acidity and calorific value were determined for the commercial ricotta as well as for the final product (FCS) (Table 4). 
Table 4. Physical and chemical characterization of commercial ricotta (1) and the (FCS) with Origanum vulgare extract (2) and Rosmarinus officinalis L. extract (3).

\begin{tabular}{lccc}
\hline & 1 & 2 & 3 \\
\hline Total dry extract (\%) & $34,86 \pm 0,15^{* \mathrm{a}}$ & $61,81 \pm 0,21^{* \mathrm{~b}}$ & $58,81 \pm 0,59^{* \mathrm{c}}$ \\
Ash (\%) & $1,53 \pm 0,03^{* \mathrm{a}}$ & $2,22 \pm 0,07^{* \mathrm{~b}}$ & $2,48 \pm 0,25^{* \mathrm{~b}}$ \\
Crude protein (\%) & $12,40 \pm 0,02^{* \mathrm{a}}$ & $8,82 \pm 0,70^{* \mathrm{~b}}$ & $10,07 \pm 0,45^{* \mathrm{c}}$ \\
Fat $(\%)$ & $14,11 \pm 0,10^{* \mathrm{a}}$ & $19,53 \pm 0,25^{* \mathrm{~b}}$ & $19,23 \pm 0,15^{* \mathrm{~b}}$ \\
Total carbohydrates (\%) & $6,82^{\mathrm{a}}$ & $31,24^{\mathrm{b}}$ & $27,03^{\mathrm{c}}$ \\
Titrable acidity $(\%$ lactic acid) & $0,192 \pm 0,006^{* \mathrm{a}}$ & $0,278 \pm 0,005^{* \mathrm{~b}}$ & $0,235 \pm 0,005^{* \mathrm{c}}$ \\
Water activity $\left(25.5^{\circ} \mathrm{C}\right)$ & $0,987 \pm 0,001^{* \mathrm{a}}$ & $0,985 \pm 0,001^{* \mathrm{a}}$ & $0,980 \pm 0,001^{* \mathrm{~b}}$ \\
pH $\left(25.0^{\circ} \mathrm{C}\right)$ & $6,10 \pm 0,01^{* \mathrm{a}}$ & $5,50 \pm 0,005^{* \mathrm{~b}}$ & $5,43 \pm 0,01^{* \mathrm{c}}$ \\
Caloric value $(100 \mathrm{~g})(\mathrm{kcal})$ & $203,87^{\mathrm{a}}$ & $336,01^{\mathrm{b}}$ & $321,47^{\mathrm{c}}$ \\
\hline
\end{tabular}

* Means of three determinations \pm standard deviation

Means followed by different letters in a similar line, statistically different from each other at $5 \%$ using Tukey's Method.

Source: Elaboration of the authors.

The protein content of the two formulations developed was lower than the protein content of the commercial ricotta (12.4\%). The product containing oregano extract contained $336.01 \mathrm{kcal} / 100 \mathrm{~g}$ or $1403.63 \mathrm{~kJ} / 100 \mathrm{~g}$, being significantly higher than the caloric value of the formulation containing rosemary extract $(321.47 \mathrm{kcal} / 100 \mathrm{~g}$ or 1342.21 $\mathrm{kJ} / 100 \mathrm{~g}$ ), which is also reflected in the higher fat and carbohydrate value. These differences in calorie, fat and carbohydrate value may be due to differences in water content of the final products with the herb extracts.

\section{Sensory Evaluation}

Both samples tested differ significantly at the level of $1 \%$ (Tukey), in the overall sensory quality, and the sample with oregano extract was the most accepted, reaching an acceptance index of $91.1 \%$. The sample containing rosemary extract showed a $76.0 \%$ acceptance rate.

The two samples were submitted to evaluation of attributes, such as color, bitter taste, acidity, salty flavor and texture/firmness, through the use of the ideal scale (Figure 4).

Figure 4. Comparison of the attributes color, bitter taste, acidity, salty flavor and texture/firmness, in both samples of FCS, evaluated by the ideal scale $(5=$ much more than the ideal; $3=$ ideal; $1=$ much less that the ideal $)$.

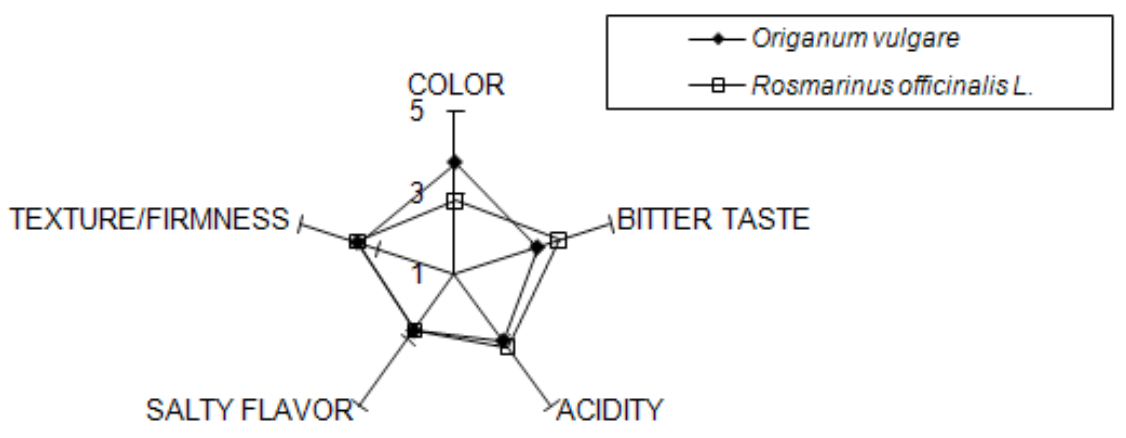

Source: Elaboration of the authors. 
The two samples differed in the color attributes $(\mathrm{P}<0.01)$, and the sample containing oregano extract was considered darker with $66.0 \%$ of the tasters found it "slightly darker than the ideal". The oregano extract had intense brown color, which resulted in a darkening of the FCS. In the assessing of sample containing rosemary extract, $70 \%$ of tasters found the color "ideal". Since rosemary extract has a light color, its addition to the FCS changed the natural color of the product very slightly. This is an expected result, since the product is based on the ricotta, and ricotta usually has a white or light yellow color.

Another attribute that should be considered is the bitter taste. The rosemary extract had an intense bitter taste, which was reflected in the sensory quality of the product. With application of the ideal scale, it was verified that $54.0 \%$ of tasters found the sample containing rosemary extract "slightly more bitter than the ideal", which was not found in the sample added to oregano extract, in which $78.0 \%$ of the tasters considered the bitter taste "ideal". Therefore, the sample containing rosemary extract was considered bitterer than the sample with oregano extract $(\mathrm{P}<0.01)$.

The attributes of salty flavor and acidity were considered "ideal" for both samples, and did not differ significantly from each other $(\mathrm{P}>0.01)$. As for texture/firmness of the sample, $50 \%$ of tasters found "ideal" the sample containing rosemary extract. However, the sample containing oregano extract, was considered "ideal" by $48.0 \%$ of tasters and "slightly firmer that the ideal" by $48.0 \%$ of the tasters.

\section{Conclusions}

The optimum conditions for extraction of phenolic compounds were $75 \%$ ethanol during 8 hours of operation for rosemary and $40 \%$ ethanol during 7.5 hours of operation for oregano.
Soluble extracts obtained from rosemary and oregano had $0.46 \mathrm{mg} \mathrm{GAE} / \mathrm{mL}$ and $2.57 \mathrm{mg}$ $\mathrm{GAE} / \mathrm{mL}$ total phenolic content, respectively. The concentrated extracts had $18.0 \mathrm{mg} \mathrm{GAE} / \mathrm{mL}$ for oregano and $9.60 \mathrm{mg} \mathrm{GAE} / \mathrm{mL}$ for rosemary.

Although rosemary and oregano extracts showed antioxidant activity in the inhibition based on the DPPH free radical formation and on the inhibition of microsomal lipid peroxidation, rosemary extract showed to be more effective as an antioxidant when compared to the oregano extract.

The fresh cheese spread formulated with oregano extracts had $396 \mathrm{mg}$ total phenolics $/ 100 \mathrm{~g}$ of final FCS product, and that corresponds to $39.6 \%$ of the Recommended Daily Intake. The acceptance rate of this product was $91.1 \%$. The product containing rosemary extract had $76.0 \%$ of acceptance, with 96 $\mathrm{mg} / 100 \mathrm{~g}$ phenolic compounds in the final product, corresponding to $9.6 \%$ of the Recommended Daily Intake.

\section{Acknowledgements}

The authors thank CNPq-Brazil, for grants to R. D. Santos.

\section{References}

AOAC. Official methods of analysis of AOAC international. 17. ed. USA: AOAC Internacional, 1995.

AYRANCI, E.; ERKAN, N.; AYRANCI, G. Antioxidant activities of rosemary (Rosmarinus Officinalis L.) extract, blackseed (Nigella sativa L.) essential oil, carnosic acid, rosmarinic acid and sesamol. Food Chemistry, v. 110, n. 1, p. 76-82, 2008.

BALDASSO, C.; BARROS, T. C.; TESSARO, I. C. Concentration and purification of whey proteins by ultrafiltration. Desalination, v. 278, n. 1-3, p. 381-386, 2011.

BHATTACHARJEE， S.; BHATTACHARJEE， C.; DATTA, S. Studies on the fractionation of $\beta$-lactoglobulin from casein whey using ultrafiltration and ion-exchange membrane chromatography. Journal of Membrane Science, v. 275, n. 1-2, p. 141-150, 2006. 
BRODKORB, A.; CHATTERTON, D. E. W.; SMITHERS, G.; ROUPAS, P. Bioactivity of b-lactoglobulin and a-lactalbumin - technological implications for processing. International Dairy Journal, Edmonton, v. 16, n. 11, p. 229-240, 2006.

CECHINI, R.; ARUOMA, O. I.; HALLIWELL, B. The action of hydrogen peroxide on the formation of thiobarbituric acid reative material from microsomes or from DNA damage by bleonycin or phenanthroline artefacts in the thiobarbituric acid test. Free Radical Research Communications, v. 10, n. 1, p. 245-258, 1990.

CHIPAULT, J. R.; MIZUN, G. K.; HAWKINS, J. M.; LUNDBERG, W. O. The antioxidant properties of natural spices. Food Research, v. 17, n. 8, p. 46-55, 1952.

CHUN, S.; SHETTY, K.; VATTEM, D. A.; LIN, Y. Phenolic antioxidants from clonal oregano (Origanum vulgare) with antimicrobial activity against Helicobacter pylori. Process Biochemistry, v. 40, n. 2, p. 809-816, 2005.

FURTADO, M. A.; ALMEIDA, L. C.; FURTADO, R. A.; CUNHA, W. R.; TAVARES, D. C. Antimutagenicty of rosmarinic acid in Swiss mice evaluated by the micronucleus assay. Mutation Research, v. 657, p. 150154, 2008.

GRANATO, D.; KATAYAMA, F. C. U.; CASTRO, I. A. Assessing the association between phenolic compounds and the antioxidant activity of Brazilian red wines using chemometrics. Food Science and Technology, v. 43, n. 10, p. 1542-1549, 2010.

HAMAGUCHI, T.; ONO, K.; MURASE, A.; YAMADA, M. Phenolic compounds prevent Alzheimer's pathology through different effects on the amyloid-beta aggregation pathway. American Journal of Pathology, v. 175, n. 6, p. 2557-2565, 2009.

HUANG, H.; HAUK, C.; YUM, M. Y.; RIZSHSKY, L.; WIDRECHNER, M. P.; McCOY, J. A. Rosmarinic acid in Prunella vulgaris ethanol extract inhibits lipopolysaccharide-induced prostaglandin E2 and nitric oxide in RAW 267.7 mouse macrophages. Journal of Agricultural and Food Chemistry, Davis, v. 57, n. 22, p. 10579-10589, 2009.

KULISIC, T.; RADONIC, A.; KATALINIC, V.; MILOS, M. Use of different methods for testing antioxidative activity of oregano essential oil. Food Chemistry, v. 85, n. 4, p. 633-640, 2004.

LAJOLO, F. M.; DUARTE-ALMEIDA, J. M.; SANTOS, R. J.; GENOVESE, M. I. Avaliação da atividade antioxidante utilizando sistema b-caroteno/ ácido linoleico e método de seqüestro de radicais DPPH. Ciência e Tecnologia de Alimentos, Campinas, v. 26, n. 2, p. 446-452, 2006.

LAWLESS, H. T.; HEYMANN, H. Sensory evaluation of food: principles and practices. New York: Chapmann \& Hall, 1998.

LOIZZO, M. R.; MENICHINI, F.; CONFORTI, F.; TUNDIS, R.; BONESI, M.; SAAB, A. M.; STATTI, G. A.; CINDIO, B.; HOUGHTON, P. J.; FREGA, N. G. Chemical analysis, antioxidant, anti-inflammatory and anticholinesterase activities of Origanum ehrenbergii Boiss and Origanum syriacum L. essential oils. Food Chemistry, v. 117, n. 1, p. 174-180, 2009.

MONOHAN, F. J.; CAPRIOLI, I.; O'SULLIVAN, M. Interference of sodium caseinate in the TBARS assay. Food Chemistry, v. 124, n. 3, p. 1284-1287, 2011.

MORENO, S.; SCHEYER, T.; ROMANO, C.; VOJNOV, A. Antioxidant and antimicrobial activities of rosemary extracts linked to their polyphenol composition. Free Radical Research, v. 40, n. 2, p. 223-231, 2006.

RAMALAKSHMI, K.; RAO, L. J. M.; TAKANOISHIKAWA, Y.; GOTO, M. Bioactivities of low grade green coffee and spent coffee in different in vitro model systems. Food Chemistry, v. 115, n. 1, p. 79-85, 2009.

RODRÍGUEZ-ROJO, S.; VISENTIN, A.; MAESTRI, D.; COCERO, M. J. ASSISTED EXTRACTION OF ROSEMARY ANTIOXIDANTS WITH GREEN SOLVENTS. Journal of Food Engineering, v. 109, n. 1, p. 98-103, 2012.

SAHIN, S.; BAYRAMOGLU, B.; SUMNU, G. SOLVENT-FREE MICROWAVE EXTRACTION OF ESSENTIAL OIL FROM OREGANO. Journal of Food Engineering, v. 88, n. 4, p. 535-540, 2008.

SCALBERT, A.; WILLIAMSON, G. Dietary intake and bioavailability of polyphenols. Journal of Nutrition, Bethesda, v. 130, n. 8, p. 2073-2085, 2000.

SIMITZIS, P. E.; DELIGEORGIS, S. G.; BIZELIS, J. A.; DARDAMANI, A., THEODOSIOU, I.; FEGEROS, K. EFFECT OF DIETARY OREGANO OIL SUPPLEMENTATION ON LAMB MEAT CHARACTERISTICS. Meat Science, Amsterdam, v. 79, n. 2, p. 217-223, 2008.

SINGLETON, V. L.; ORTHOFER, R.; LAMUELARAVENTÓS, R. M. Analysis of total phenols and other oxidation substrates and antioxidants by means of FolinCiocalteu reagent. Methods in Enzymology, v. 299, p. 152-179, 1999. 
SUHAJ, M. Spice antioxidants isolation and their antiradical activity: a review. Journal of Food Composition and Analysis, v. 19, n. 6-7, p. 531-537, 2006.

TARHAN, L.; NAKIBOGLU, M.; UREK, R. O.; KAYALI, H. A. ANTIOXIDANT CAPACITIES OF ENDEMIC SIDERITIS SIPYLEA AND ORIGANUM SIPYLEUM FROM TURKEY. Food Chemistry, v. 104, n. 2, p. 630-635, 2007.

TEPE, B. Antioxidant potentials and rosmarinic acid levels of the methanolic extracts of Salvia virgata (Jacq), Salvia staminea (Montbret \& Aucher ex Bentham) and Salvia verbenaca (L.) from Turkey. Bioresource Technology, Miramar, v. 99, n. 6, p. 1584-1588, 2008.
XAVIER, C. P.; LIMA, C. F.; FERNANDES-FERREIRA, M.; PEREIRA-WILSON, C. Salvia fruticosa, Salvia officinalis, and rosmarinic acid induce apoptosis and inhibit proliferation of human colorectal cell lines: The role in MAOK/ERK pathway. Nutrition and Cancer, $\mathrm{n}$. 61, p. 564-571, 2009.

YANG, H.; HSEU, Y.; CHANG, W.; CHEN, C.; LIAO, J.; HUANG, C.; LU, F.; CHIA, Y.; HSU, H.; WU, J. Antioxidant activities of Toona Sinensis leaves extracts using different antioxidant models. Food and Chemical Toxicology, v. 46, n. 1, p. 105-114, 2008. 